\title{
BINDING OF CORTICOSTEROIDS BY PLASMA PROTEINS. II. PAPER ELECTROPHORESIS AND EQUILIBRIUM PAPER ELECTROPHORESIS 1,2
}

\author{
By WILLIAM H. DAUGHADAY \\ (From the Department of Internal Medicine, Washington University School of Medicine, \\ St. Louis, Missouri)
}

(Submitted for publication August 2, 1956; accepted September 5, 1956)

Dialysis equilibrium experiments indicate that corticosteroids circulate largely in loose association with plasma proteins (2). When separate fractions of human plasma prepared by the low temperature, alcohol method of Cohn were subjected to dialysis equilibrium against phosphate buffer containing hydrocortisone, Fraction V, largely albumin, proved to have the highest affinity for hydrocortisone.

Additional evidence concerning the nature of the plasma proteins responsible for binding of corticosteroids would be desirable. Paper electrophoresis has been used successfully to characterize the binding of thyroxine (3). An alpha globulin was found to possess the greatest affinity for thyroxine although albumin also may be important in thyroxine binding under certain circumstances. An attempt to apply paper electrophoretic methods to the study of corticosteroid binding has been made by Westphal, Firschein, and Pearce (4). Hydrocortisone-4- $\mathrm{C}^{14}$ was added to human serum albumin and subjected to electrophoresis. After development of the electrophoresis the steroid was eluted in strips from the paper and the quantity of radioactivity measured. No migration of hydrocortisone from the starting line was observed. When the same procedure was applied to serum albumin to which progesterone-4-C ${ }^{14}$ had been added, there was a migration of the progesterone with the current, but the steroid was not localized to the albumin component.

In this paper, electrophoretic studies of binding of corticosterone and hydrocortisone by plasma proteins are presented. The standard paper elec-

\footnotetext{
${ }^{1}$ Reported in part at the Annual Meeting of the American Society of Biological Chemists, April, 1956 (1).

2 This investigation was supported by a research grant, C-255(C3), from the National Institute of Arthritis and Metabolic Diseases, of the National Institutes of Health, Public Health Service.
}

trophoretic method has been compared with a new method which makes possible the study of the binding of uncharged substances with low affinity for proteins.

\section{METHODS}

Sheets of Whatman No. 3 MM filter paper, $18 \%$ by $91 / 2$ inches, were used for electrophoresis between glass plates, as described by Chernoff (5). The avoidance of evaporation such as occurs in most free strip electrophoretic devices is important for binding studies. The edges of the glass plates were sealed with tape to inhibit evaporation further. Barbital buffer $\mathrm{pH} \mathbf{8 . 8}$ with an ionic strength of 0.06 was used. Electrophoresis was carried out with a current of 180 to 220 volts for a period of from 8 to 14 hours.

Crystalline bovine plasma albumin was obtained from Armour Laboratories. Samples of human Fraction V were provided by Dr. J. Newton Ashworth of the American Red Cross. Blood was drawn from normal human adult laboratory workers and the plasma separated promptly. The Endocrinology Study Section of the National Institutes of Health allotted the corticosterone4- $\mathrm{C}^{14}$ and hydrocortisone-4- $\mathrm{C}^{14}$ each with a specific activity of 1.467 microcuries per millimole.

In most experiments $0.2 \mathrm{ml}$. of the protein solution containing the radioactive steroid was applied to a starting line of 4 to 6 inches in length. After completion of the electrophoresis, the paper was dried in an oven at $100^{\circ} \mathrm{C}$, and the position of the proteins was identified by staining with bromphenol blue. Vertical strips, 0.5 inch in width, were cut from the paper. Each strip was then further cut up into small pieces and placed in a test tube. The steroids were extracted from the paper with three 5-ml. portions of ethyl alcohol. The alcohol extract was filtered, pooled and evaporated in $50 \mathrm{ml}$. conical centrifuge tubes. Radioactivity was determined by transferring the extracts in ethyl alcohol to brass cups with an inside diameter of $2 \mathrm{~cm}$. and containing a disk of lens paper, and drying under an infra red lamp. A Robinson gas flow proportional counter was used to measure the radioactivity. Where a measure of the absolute rather than the relative radioactivity was desired, the transfer was accomplished in $0.6 \mathrm{ml}$. of 80 per cent ethyl alcohol containing 2 per cent glucose. The glucose fixed the lens paper to the brass cup and provided a uniform glaze 
FIG. 1A
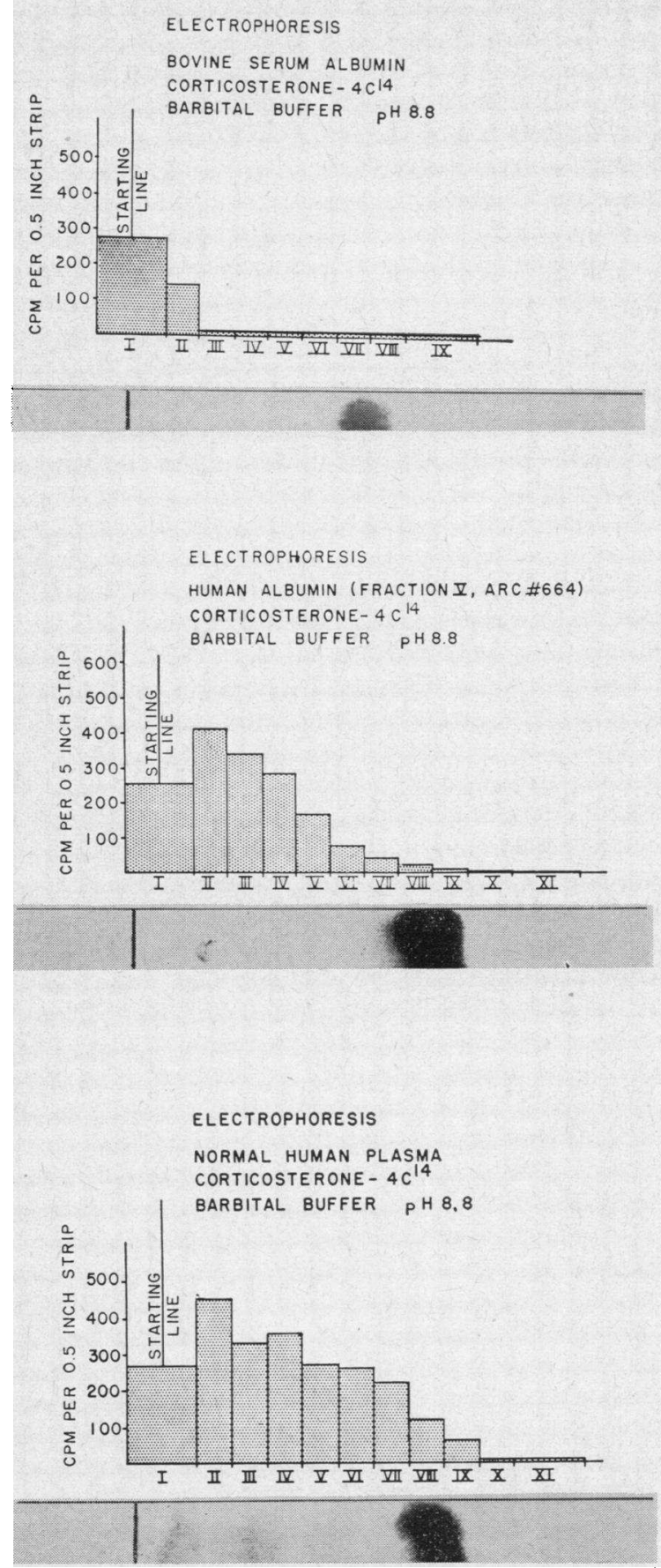

FIG. 1B
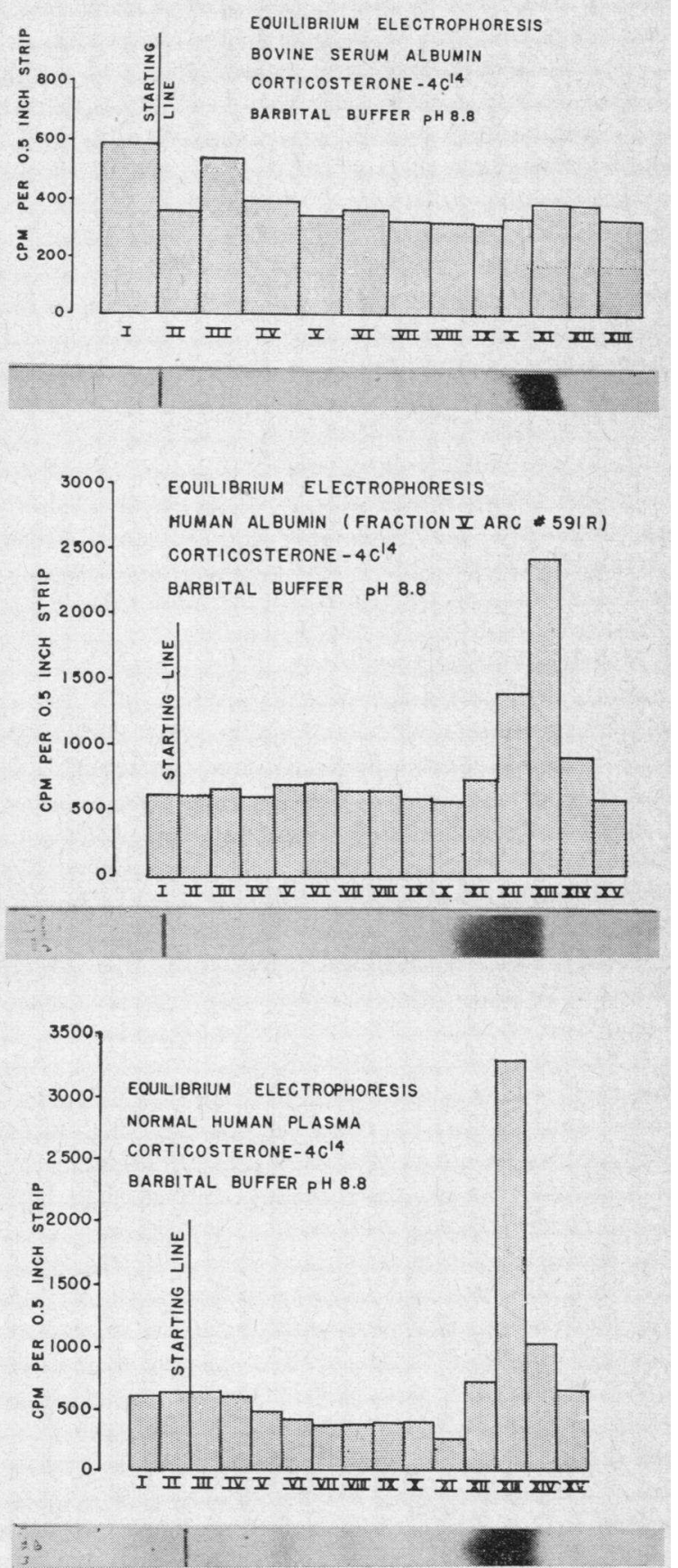

Fig. 1. Conventional Paper Electrophoresis (1A) and Equilibrium Paper Electrophoresis (1B) of Bovine Serum Albumin (Upper Graphs), Human albumin (Middle Graphs) and Normal Human Plasma (LOWER GRAPHS)

The stippled columns indicate the relative amounts of radioactivity found in strips cut vertically to the axis of electrophoresis. Below each graph a strip of paper stained with bromphenol blue indicates the location of the albumin component. The albumin concentrations were 4 per cent except in the case of equilibrium electrophoresis with human albumin (Fraction V) where an 8 per cent solution was used. 
after drying under an infra red light. Correction for self absorption was calculated on the basis of weight from an experimentally determined self-absorption curve.

In the technique of equilibrium paper electrophoresis, preliminary equilibrium of the protein solution and the electrophoretic buffer was achieved. The plasma or protein solution, $10 \mathrm{ml}$. in a cellophane bag (Visking, 18/32 Nojax Casing), was dialyzed for 24 hours against $40 \mathrm{ml}$. of barbital buffer containing about $20 \mathrm{mcg}$. of $\mathrm{C}^{14}$-labelled steroid. At the conclusion of the dialysis the paper used for electrophoresis was soaked with the dialysate, and the protein solution was applied to the starting line as described above.

\section{RESULTS}

Corticosterone-4- $\mathrm{C}^{14}$ was added to bovine plasma albumin, human albumin (Fraction V) and normal human plasma and subjected to paper electrophoresis in the conventional manner (Figure 1A). Significant migration of the radioactivity did not occur with bovine plasma albumin. More of the corticosterone moved in the presence of human albumin, but the greatest movement of corticosterone occurred with normal human plasma. Even with normal human plasma, however, the radioactivity was not associated with a particular protein peak but decreased in a progressive manner from the starting line. In control experiments with corticosterone-4-C ${ }^{14}$, in the absence of protein there was no obvious migration of steroid from the starting line.
The failure to demonstrate the association of radioactivity with particular proteins in the conventional electrophoresis technic was attributed to the loose and reversible character of the steroid protein bond. As the steroid binding protein advances along the paper a continuous dissociation from the protein occurs with loss of steroid from the moving protein component. The technic of equilibrium paper electrophoresis was designed to maintain the protein in the same free steroid environment that existed during the preliminary dialysis. Under the conditions of equilibrium electrophoresis the rate of association of new steroid with the protein should approximate the rate of dissociation.

The binding of corticosterone-4-C $\mathrm{C}^{14}$ by bovine and human albumin and by normal human plasma has been examined with the technic of equilibrium electrophoresis (Figure 1B). There was little concentration of radioactivity with the protein peak of bovine albumin. Increase in the protein concentration from 4 to 8 per cent did not improve resolution. In contrast, there was clear localization of corticosterone with the migrating component of human albumin. An even greater localization of radioactivity with the albumin of normal human plasma could be demonstrated.

Parallel experiments have been carried out

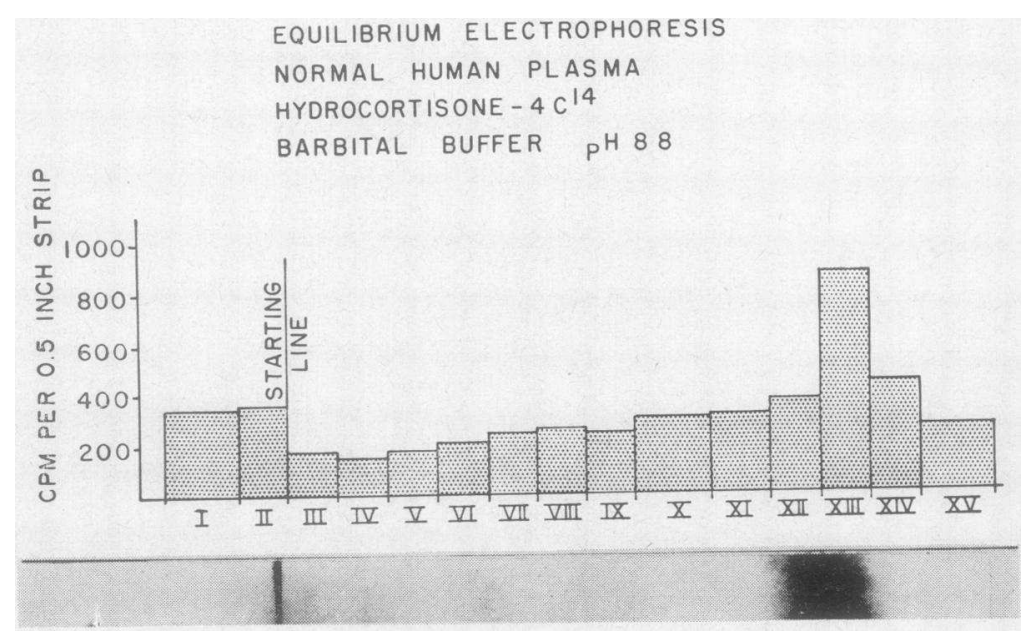

Fig. 2. Equilibrium Paper Electrophoresis of Normal Human Plasma AND HYDROCORTISONE-4- $\mathrm{C}^{14}$

The stippled columns indicate the radioactivity found in strips cut vertically to the axis of electrophoresis. A strip of paper stained with bromphenol blue indicates the position of the albumin component. 
with hydrocortisone-4-C $\mathrm{C}^{14}$, and again no meaningful results were obtained with standard paper electrophoretic methods. The binding of hydrocortisone by the albumin component of normal human plasma could be demonstrated clearly by equilibrium electrophoresis (Figure 2). The localization with hydrocortisone was less clearly evident than with corticosterone. This finding could be correlated with the fact that the affinity of corticosterone for albumin is more than twice that of hydrocortisone, as determined by direct radiochemical measurement of the corticosterone-4- $\mathrm{C}^{14}$ in the protein solution and the dialysate.

\section{DISCUSSION}

The limitations of paper electrophoresis in the study of protein binding of substances such as corticosteroids with relatively low affinity for proteins have been clearly demonstrated. Because of the dissociation of the steroid from the protein, localization with individual protein components cannot be obtained. Westphal, Firschein, and Pearce (4) have inquired whether the greater paper electrophoretic migration of progesterone as compared to hydrocortisone in albumin solution could be attributed to a greater affinity of the hydrocortisone to the paper. Chromatography with barbital buffer actually showed that the reverse was true. The strength of the steroid-protein bond was therefore paramount in determining mobility in paper electrophoresis. The present findings indicate that the major factor promoting dissociation of the steroid is the buffer rather than the paper. Impregnating the paper with buffer containing the corticosteroid in equilibrium with human plasma has permitted continued migration of increased steroid concentration with the albumin component of plasma. It would seem unlikely that the minute concentration of steroid in the buffer could saturate the binding sites for steroid in the paper. Furthermore, when the concentration of steroid was highest in the buffer, as in the runs with bovine albumin, the definition of binding was much poorer than with human plasma when the steroid concentration in the buffer was lower. It may be concluded that the equilibrium between corticosteroid, buffer and protein is not greatly disturbed by the presence of the filter paper.
A graded affinity for corticosteroids has been demonstrated in the proteins studied. Normal human plasma bound the two corticosteroids more strongly than Fraction V. The latter in turn was more potent than bovine plasma albumin. The binding affinity of the last protein was so little that the localization was barely demonstrable by equilibrium electrophoresis. Direct measurement of the radioactivity in protein samples and dialysate prior to electrophoresis demonstrated that the affinity of normal human plasma for hydrocortisone was about eight times greater than that of bovine plasma albumin at the $\mathrm{pH}$ of the barbital buffer. The present observations on the differences in the affinity of different albumins for steroids confirm those obtained by dialysis equilibrium (2) and by spectrophotometric studies of binding of progesterone (6). The explanation for these differences cannot be given as yet. There is no evidence of inhomogeneity of the albumin by electrophoresis but it is possible that there is a separate steroid binding protein migrating with the human albumin component. It is possible that the differences between bovine and human albumin may have been induced by fractionation. The close correspondence of the peak of steroid concentration with the albumin component argues against the possibility that the diffuse lipoprotein component which extends from the $\beta$-globulins into and sometimes beyond albumin on paper electrophoresis (7) is responsible for protein binding of corticosteroids.

\section{SUM MARY}

1. Standard paper electrophoresis failed to indicate the association of corticosterone-4- $\mathrm{C}^{14}$ with bovine plasma albumin, human albumin (Fraction V) or with any separate protein component of normal human plasma.

2. Preliminary dialysis of the protein solution to be studied with the electrophoretic buffer containing either corticosterone-4- $\mathrm{C}^{14}$ or hydrocortisone-4-C ${ }^{14}$ has allowed the demonstration of the electrophoretic migration of the bound corticosteroid exclusively with the albumin component of normal plasma.

3. The affinity of corticosterone-4- $C^{14}$ and hydrocortisone-4-C $\mathrm{C}^{14}$ was greatest for normal human 
plasma, intermediate for human albumin (Fraction $\mathrm{V}$ ), and least for bovine plasma albumin.

\section{ACKNOWLEDGMENTS}

The author is indebted to Mrs. Carolyn Hartnett Collins for technical assistance, and to Dr. Amos Chernoff for advice on paper electrophoretic methods.

\section{REFERENCES}

1. Daughaday, W. H., and Hartnett, C., Binding of corticosteroids by plasma proteins. Federation Proc., 1956, 15, 238.

2. Daughaday, W. H., Binding of corticosteroids by plasma proteins. I. Dialysis equilibrium and renal clearance studies. J. Clin. Invest., 1956, 35, 1428.
3. Larson, F., Deiss, W. P., and Albright, E. C., Localization of protein-bound radioactive iodine by filter paper electrophoresis. Science, 1952, 115, 626.

4. Westphal, U., Firschein, H. E., and Pearce, E. M., Binding of hydrocortisone-4-C ${ }^{44}$ and progesterone$4-\mathrm{C}^{14}$ to serum albumin demonstrated by paper electrophoresis. Science, 1955, 121, 601.

5. Chernoff, A. I., The human hemoglobins in health and disease. New England J. Med., 1955, 253, 322.

6. Westphal, U., Spectrophotometric demonstration of interaction between proteins and $\Delta^{4}-3$-ketosteroid hormones. Federation Proc., 1956, 15, 382.

7. Rosenberg, I. N., Serum lipids studied by electrophoresis on paper. Proc. Soc. Exper. Biol. \& Med., 1952, 80, 751. 